\title{
SOCIAL RESPONSIBILITY AND ITS ENVIRONMENTAL COMPONENT: ORIGINS, EVOLUTION AND ORGANIZATIONS INVOLVED
}

\author{
Valentina-Mariana Mănoiu ${ }^{1 *}$ and Alexandru Valeriu Gâdiuţă ${ }^{2}$ \\ ${ }^{1}$ Assoc. Prof. Dr., University of Bucharest, Faculty of Geography, ROMANIA, \\ valentina.mariana.manoiu@gmail.com \\ ${ }^{2}$ Councillor, General Council of Bucharest, ROMANIA, alexandru.gadiuta@gmail.com \\ ${ }^{*}$ Corresponding author
}

\begin{abstract}
This paper deals with a very important subject for both developed and developing countries, one that has yet to be thoroughly analyzed from an environmental perspective: corporate social responsibility. Our analysis is highly relevant in our current context, given the increasing pressures exerted by companies on the environment as a result of their economic activities. Furthermore, another element that makes this study upto-date is the fact that more and more companies have started to pay attention to the concept of corporate social responsibility and have begun to take responsibility for these pressures and act towards reducing them, whether out of voluntary compliance or forced by market conditions or regulatory bodies. The present study is a historical descriptive-analytic investigation of the concept of corporate social responsibility and its environmental component. The aim of the research is to create a historical analysis of this concept and its environmental aspects at the international level, presenting at the same time the various organizations and programs involved in its development and in the actions, that help implement it. The social responsibility of companies, also known as corporate social responsibility (CSR) or, in French, responsabilité sociétale des entreprises (RSE), is a fundamental component of the broader concept of social responsibility. There is no unanimously accepted version for the birth of this notion or its first proposed definitions. In time, the importance of CSR has steadily grown, and it became the focus of attention not just for theoreticians and companies, but also for international organizations, such as the Organization for Economic Co-operation and Development (OECD), the United Nations (UN), the Global Compact Program, the ISO 26000 Social Responsibility Standard or the European Union. We can thus say that a new stage began for the evolution of corporate social responsibility, where the most important aspects are the planning and subsequent implementation of its underlying concepts. Corporate social responsibility received significant attention from international organizations, and this served as a strong incentive for the business environment to adopt the concept. From an environmental standpoint, corporate social responsibility is becoming increasingly important, due to the pressures exerted by companies on the natural world. At an international level, most major corporations have accepted the principle of the responsibility that they have towards society for the environmental impact generated by their economic activities. This acceptance has been followed by the adoptions of internal operational policies aimed at reducing the said impact. Corporate social responsibility is not just an act of philanthropy or a fad, but a very serious behavior which should serve as a foundation for the actions of a corporation and that will naturally lead to long-term profits.
\end{abstract}

Keywords: corporate social responsibility, environment, economy, international organizations

\section{PURPOSE OF THE STUDY}

This paper deals with a very important subject for both developed and developing countries, one that has yet to be thoroughly analyzed from an environmental perspective: corporate social responsibility.

Our analysis is highly relevant in the current context, given the increasing pressures exerted by companies 
on the environment as a result of their economic activities. Furthermore, another element that makes this study up-to-date is the fact that more and more companies have started to pay attention to the concept of corporate social responsibility and have begun to take responsibility for these pressures and act towards reducing them, whether out of voluntary compliance or forced by market conditions or regulatory bodies.

The present study is a historical descriptive-analytic investigation of the concept of corporate social responsibility and its environmental component. The aim of the research is to create a historical analysis of this concept and its environmental aspects at both national and international level, presenting at the same time the various organizations and programs involved in its development and in the actions, that help implement it.

\section{BACKGROUND}

The concept of corporate social responsibility does not have a single, well-established definition. It is a complex notion, whose content varies depending on the angle from which it is analyzed and the manner in which researchers approach it.

An overview, in a wider context, or a detailed study of one of its facets can generate different versions or definitions. Additionally, the same author can come up with more than one version of his own definition over time, due to the changes suffered by the concept.

By looking in the Dictionary of the Romanian Language (Dictionary of the Romanian Language, 1998), we found the following definitions:

Responsibility is an obligation to do something, to answer in front of someone, to be held accountable, to accept and to suffer the consequences. It is a duty, a function, something for which a person is responsible It comes from the French word responsabilité.

Social is an adjective that characterizes something that is related to society, which is specific to society and is connected to the existence of people in a society, the relationships between individuals and between people and the society. It is also something that is specific to a certain type of society or is connected to a certain social class or social group. This word also comes from French (social) and has its origins in Latin (socialis).

Starting from this semantic analysis of the two words, we will try to create a preliminary definition, by joining the two explanations:

\section{Social responsibility means responsibility/accountability towards society.}

Human society, where we all live, is a giant system whose components are constantly interacting with each other. Each entity has a certain degree of influence over the others and on the general equilibrium. From this point of view, we could say that social responsibility is a general concept that concerns every member of the society.

As human society evolved and population increased, along with technological capabilities, so did human pressures on the environment. Since the pressure exerted by each individual and by the society at large is now greater than ever before, our responsibility for the actions that we take must also increase. Thus, the importance of the general concept of social responsibility is constantly growing. Economic activities are very important through their impact and their influence on human society and the environment. Consequently, the notion of social responsibility among economic actors is becoming all the more vital, as production and consumption steadily rise.

A general definition of the concept of social responsibility offered by the Cambridge Business English Dictionary (2011) reads as follows: Social responsibility is the practice of producing goods and services in a way that is not harmful to society or the environment.

\section{THE CONCEPT OF CORPORATE SOCIAL RESPONSIBILITY- INTERNATIONAL EVOLUTION}

The social responsibility of companies, also known as corporate social responsibility (CSR) or, in French, responsabilité sociétale des enterprises (RSE), is a fundamental component of the broader concept of social responsibility. There is no unanimously accepted version for the birth of this notion or its first proposed definitions.

Numerous experts in this field (Carroll, 1999, p. 270) see Howard R. Bowen, an American economist, as the 
"father" of the corporate social responsibility theory. In 1953, he published a book titled Social Responsibilities of the Business Man, where we can find the following definition (Bowen, 1953, p. 6): "social responsibility refers to the obligations of business men to pursue those policies, to make those decisions, or to follow those lines of action which are desirable in terms of the objectives and values of our society."

Afterwards, in 1960, the American economist Keith Davis brought forward the following motivation for adopting a responsible corporate behaviour (Davis, 1960, p. 70), saying that it could lead to "long-run economic gains". Once again, in 1973, Keith Davis formulated "The Iron Law of Social Responsibility" (Davis, 1973 , p. 314), where he stated that, by lacking a socially responsible behaviour, a company will lose its power. It is possible to see how, over time, people became more and more aware of this concept: from the motivation of a long-term gain generated by a responsible conduct (optional character) to the need for such a behaviour, whose absence would lead to a loss of power (mandatory character). As economists started to pay more attention and analyze the concept, voices emerged saying that corporate social responsibility is not as important as it seemed. One of the best known such opinions belongs to economist Milton Friedman. A winner of the Nobel Prize in Economics in 1976, he wrote in 1970 that "Only people have responsibilities, but "business" as a whole cannot be said to have responsibilities" (Friedman, 1970, p. 33). Friedman argues that, in a free market, the only social responsibility of a company is to manage its resources so as to maximize its profit without committing an illegal act. The profit will then be redistributed to the society, through taxes paid to the state, the salaries of its employees and benefits for its shareholders.

In 1984, Edward Freeman, an American professor of business administration, offered a new perspective on the issue of corporate social responsibility in his book, Strategic Management (Freeman, 1984). He believes that profit is a consequence of a company's economic activity, and a company should act in a manner that takes into account the interests of all stakeholders (employees, suppliers, partners, neighbours etc.) because such a responsible behaviour will also lead to profit. On the contrary, if a company does not pursue such a course of action, it will lead, in the long-term, to losses or even bankruptcy. Such a perspective on the way in which a company functions is a motivation for pursuing a responsible conduct. The formulation of this perspective gave new impetus to the field of corporate social responsibility, highlighting the fact that it is not just a philanthropic act or a fad but a very serious behaviour that should serve as the foundation for the functioning of a corporation and which will naturally lead to long-term profits.

\section{ORGANISATIONS AND PROGRAMS INVOLVED IN THE DEVELOPMENT OF CORPORATE SOCIAL RESPONSIBILITY}

In time, the importance of CSR has steadily grown, and it became the focus of attention not just for theoreticians and companies, but also for international organizations. We can thus say that a new stage began for the evolution of corporate social responsibility, where the most important aspects are the planning and the subsequent implementation of its underlying concepts.

The attention of international organizations was very important and served as a strong incentive for the business environment to adopt the concept.

\subsection{The Organization for Economic Co-operation and Development (OECD)}

OECD was among the first international organisms involved in the field of corporate social responsibility. OECD (Romanian Ministry of Foreign Affairs site) is an intergovernmental forum that aims to identify, disseminate and evaluate the implementation of public policies that lead to sustainable economic growth and social stability. It has 34 member states that together represent more than $70 \%$ of the global economic output and trade and $90 \%$ of global foreign direct investments (OECD site), thus being a significant international organism.

In 1976, OECD published the "Guidelines for Multinational Enterprises", a set of directives that should be followed by any company, no matter its field of activity, concerning environmental protection, human rights, consumer protection, corruption, and competition. This set of best practices works towards the development of a responsible behaviour among companies, in view of achieving a sustainable economic development. The latest version of this document was published by OECD in 2011 , and is the fifth update of the original guidelines.

\subsection{The United Nations (UN)}

The United Nations (UN) is one of the most important and influential international organizations, comprising at the moment 193 member states. Among its major goals, we encounter the protection of the environment, 
the fight against climate change and sustainable development (United Nations site).

During its history, the UN has included on its agenda the subject of environmental protection, in an attempt to bring together world leaders in order to discuss and agree on global action plans. The strength of this organization comes from its ability to gather "at the same table" representatives from almost all countries and launch discussions or raise the alarm with regards to certain issues. Unfortunately, it is not always possible to arrive at a unanimously accepted solution or action program, and in many cases the solutions that are agreed contain numerous compromises and concessions, weakening their effectiveness. In this section of our paper, we will highlight the main projects and programs of the United Nations in the field of corporate social responsibility and also with regards to the environment and the topic of sustainable development, which are both closely related to CSR.

In 1969, at the proposal of Sweden, the UN decided to organize the first global conference on the environment (Romanian Ministry of Environment and Climate Change site). It took place in Stockholm, in 1972, under the slogan "One Earth", and was attended by delegates from 114 states, including Romania. The conference concluded with the following results:

- The Stockholm Declaration, containing 26 points about the environment and development and an Action Plan for the Human Environment, with 109 recommendations, founded on three basic components:

- The Global Environmental Evaluation Program (Earthwatch)

- Activities for environmental management

- Support measures.

The 109 recommendations, aimed at all states, lacked binding force and were to be implemented by means of national regulations that would be in accordance with these texts. Thus, this plan led to the subsequent adoption of a number of national and international measures, such as:

- The Sea Charter (for protecting the Baltic Sea or the Black Sea) and documents concerning the protection of Antarctica.

- The United Nations Environment Programme - UNEP

- The Global Environment Facility

- A UN resolution on the subject of environmental protection

In 1983, the United Nations established the World Commission on Environment and Development (Romanian National Agency for Environmental Protection site), whose main objectives are to study the dynamics behind environmental degradation and to find solutions for the long-term survival of human society. This commission was led by Gro Harlem Brundtland, the prime minister of Norway at that time. The Brundtland Commission identified two major problems:

- Economic development is only concerned with ever-growing profits and higher standards of living for a small percentage of the world's population, without raising the general quality of life.

- Accelerated economic development often leads to destruction and an irrational use of natural resources, resulting in widespread pollution of the environment.

The Brundtland Commission, after finalizing the consultations, published a document titled "Our Common Future" (the Brundtland Report), where it laid the foundations for what was to become Agenda 21, and the principles of the Rio Declaration. In this document, sustainable development is defined as "a development that answers present needs without compromising the ability of future generations to satisfy their own needs" (WCED, 1987, p. 24).

In 1992, the UN organized the United Nations Conference on Environment and Development (UNCED) in Rio de Janeiro, also known by its shorter name of "the Rio Conference", where 120 states took part.

This conference marked the international recognition of the need to integrate responsible economic development and environmental protection into the goal of achieving a sustainable development and reaffirmed the growing importance of international environmental law, which must establish a regulatory framework for economic actors (UNCED, 1992).

The conference resulted in the following documents (The United Nations, 1992):

- The Rio Declaration, comprising 27 principles; 
- Agenda 21, an action plan for sustainable development in the $21^{\text {st }}$ century, consisting of 40 chapters targeting specific programs, structured according to:

- The action base;

- Goals that need the be reached;

- Activities that must be carried out;

- Methods of implementation;

- The Statement of Principles on Forests " (World Commission on Forests and Sustainable Development, 1999) -a non-binding document that includes principles and recommendations for managing the preservation and sustainable development of all types of forests;

- The institutional organization of the Commission for Sustainable Development (CSD);

- The funding mechanism for implementing Agenda 21.

The Rio Summit is very important because it brought to the public sphere the problems facing our environment, and thus helped governments and world leaders to become more aware of them. Together with Agenda 21 and the Rio Declaration, two binding international treaties were also agreed:

- The Convention on Biological Diversity (CBD) and

- The United Nations Framework Convention on Climate Change (UNFCCC).

In 1997, at its New York headquarters, the UN organized a new world conference for evaluating the implementation process of the policies for protecting the environment that were agreed at the Rio Conference in 1992 (The United Nations, 1997). The main issues that were highlighted were: the failure of improving technology transfer and capacity building for participation and development; the failure of achieving institutional coordination and the inability to reduce excessive levels of consumption and production.

In 2002, Johannesburg hosted the World Summit on Sustainable Development - WSSD, where leaders from 104 countries participated. The main results were:

- The Johannesburg Declaration on sustainable development

- The Plan of Implementation of the World Summit on Sustainable Development (JPOI).

The Johannesburg Summit confirmed once again the fundamental idea that sustainable development must be at the forefront of international talks, and sent a strong signal for the implementation of a global action plan for environmental protection. One of the main ideas that resulted from the debates was the existence of a very strong correlation between living standards, the environment and the use of natural resources.

The Johannesburg declaration speaks openly about a collective responsibility, which needs to be assumed by everyone in order to achieve progress, and also mentions three interdependent objectives: economic development, social development and the protection of the environment. Only by reaching all of these closely related goals can we attain a harmonious and durable development (The United Nations, 2002). Furthermore, the summit recognized the pivotal role played by civil society in the process of achieving sustainable development and the effectiveness of the partnerships where it was involved (La Vina et al, 2003). This is a very important aspect for the area of corporate social responsibility, because the involvement of civil society and non-governmental organizations has been strong, and this indirect recognition serves as an encouragement for future projects.

In 2012, the UN organized the United Nations Conference on Sustainable Development, (UNCSD) in Rio de Janeiro, 20 years after the United Nations Conference on Environment and Development (UNCED). It was attended by 192 states, represented by 57 heads of state and 31 prime-ministers. The conference was based around three core objectives: the need for states to assume once more sustainable development as a political engagement, the follow-up of objectives set during previous conferences and the establishment of an action plan for the future.

The debates targeted two main themes:

- The Green Economy - ways of building and supporting less developed states in order to adopt this economic model;

- The creation of an international institutional framework for improving international coordination in the 
area of sustainable development.

\subsection{The Global Compact Program}

In 1999, during the World Economic Forum in Davos, the UN Secretary General, Kofi Annan, appealed to the business world to participate in a new program initiated by the United Nations, the Global Compact, which sought to involve the business community in sustainable development projects by following a responsible business conduct.

The Global Compact Program was officially launched at UN's New York headquarters in 2000. It is an initiative that encourages companies to adopt a responsible social behaviour and sustainable policies. Economic entities are also expected to periodically present reports on the evolution of the implementation and functioning of these policies.

This program brings together, as partners and collaborators, the business environment, represented by the companies that choose to participate, UN agencies and members of the civil society. Companies that wish to become part of this global network have to include in their internal operational policies ten fundamental principles from the areas of human rights, the environment and the fight against corruption.

The three principles related to environmental protection are:

- Principle 7: Companies must promote a precautionary approach to ecological issues;

The concept of precautionary approach was incorporated in the Rio Declaration of 1992 and states that "in case of a risk of severe or irreversible damage, the lack of absolute scientific certainty shall not be used as a reason for postponing effective measures in order to prevent environmental degradation" (The United Nations, 1992). This principle requires a preventive attitude from the part of companies, which should act in case of a situation that poses a threat to the environment. Such a conduct can have an entirely pragmatic motivation, of an economical nature, since prevention has been proven to cost less than what it would be necessary to repair damage caused to the environment. On the basis of this principle, companies are encouraged to adopt transparency in their activities and communicate with the public. Through continuous interactions with the outside environment, a company can better understand its influence and can be informed more easily with regards to aspects that may threaten the environment.

- Principle 8: Companies must undertake actions for promoting a higher degree of ecological responsibility;

First and foremost, companies that take up these principles agree, through their own internal policies, to reduce as much as possible the environmental impact of their activities. According to the Global Compact, the steps that a company must follow for promoting environmental responsibility are:

- Defining a vision for the company, policies and strategies that include the principles of sustainable development, a prosperous economy, environmental quality and social justice.

- Defining, in a voluntary manner, targets, plans and indicators that must be reached.

- Establishing a sustainable program of production and consumption, with clear objectives.

- Collaborating with all elements of the economic circuit (raw material suppliers, service providers, distributors, producers), for attaining better outputs and a higher degree of efficiency, that would lead to a reduction of the environmental impact of economic activities.

- Drafting periodical activity reports on the evolution of the implementation process for responsible environmental policies. These reports should be analyzed and actions ought to be taken in order to continuously improve the situation.

- Ensuring transparency and dialogue with all stakeholders on environment-related subjects.

- Principle 9: Companies must encourage the development and adoption of environmentally friendly technologies.

This principle states that economic entities must adopt technologies that cause the least amount of pollution possible, manage resources in an efficient manner, generate recyclable waste and include efficient waste management systems in their production activities. A company that chooses to become a member of the Global Compact project must, in addition to abiding by the 10 principles of the program, publicly express its involvement in the program and the values that it promotes by all available media channels. Participating companies are also required to submit an annual report that shall present the progress achieved with 
regards to the implementation of corporate social responsibility policies in their actions. The report will be drafted in accordance with an official template.

In addition to companies, the Global Compact is open to academic institutions, associations representing businesses or industries, non-governmental organizations, trade unions and public sector institutions. Starting from 2002, a new subcategory was launched - Global Compact Cities, with Melbourne, in Australia, being the first city accepted. The goal of this new endeavour is to encourage local administrations to follow a sustainable model of urban development, which minimizes environmental impacts. Another aim is to foster dialogue and the exchange of best practices among local administrations and also between them and the business environment, members of the civil society etc. As of 2013, 80 cities have joined the program. This growth continued, and, in 2016, 130 cities from all continents were enrolled (The Global Compact Cities Programme site). Currently, the Global Compact Program of the United Nations is seen as the most important world-wide program in the field of corporate social responsibility, with 12.000 members from 170 countries. Among them 8000 are companies and the other 4000 are various entities (United Nations global compact site).

\subsection{The ISO 26000 Social Responsibility Standard}

The International Organization for Standardization (I.S.O.) is an international non-governmental organization that consists of a network of 161 national standardization institutes (ISO site). Unlike the UN, its members are not delegates of national governments. Nevertheless, I.S.O. occupies a special position between the public and the private sectors. This is mainly due to the fact that many members of the institutes belong to national governmental structures and are empowered by state authorities (Free Audit site). For this reason, I.S.O. can act as bridge in the process of creating consensus on solutions that meet, at the same time, the needs of commercial activities and the needs of society in general.

The ISO 26000 Social Responsibility Standard was finally defined after 10 years of studies and negotiations carried out at international level. It opened the way for a new class of standards, based on a participative and consensual approach, aiming to elaborate recommendations under the guise of "guidelines". Its creation began in 2000, when the International Organization for Standardization announced its intention to contribute to the formulation of a "universal framework of values" in the area of social responsibility, by harmonizing the multitude of codes, norms, certifications and standards existing in the social and environmental fields.

In 2005, the drafting of the ISO 26000 standard began, undertaken by a international expert group that, over the following years, would include more than 450 experts and 210 observers from 99 ISO member states, as well as from 42 major international organizations, such as the International Labour Organization (ILO), the United Nations Environment Programme (UNEP), the Organisation for Economic Cooperation and Development (OECD), the Global Reporting Initiative (GRI). The official text was published in 2010.

The ISO 26000 Standard defines social responsibility as "the responsibility of an organization for the impact of its decisions and activities on society and the environment, by means of an ethical and transparent behaviour, which contributes to sustainable development, takes into account the expectations of stakeholders, respects existing laws and is consistent with international norms of behaviour, is integrated throughout the organization and practised in its activities". ISO 26000 identifies 7 core issues that organizations must approach in an integrated manner. It offers information on the purpose, relationship with social responsibility, basic principles and actions that need to be correlated. The seven main subjects are:

- Organizational governance - incorporating the 7 principles of social responsibility into decisional and operational processes.

- Human rights - civil and political rights, as well as economic, cultural and social rights.

- Working conditions - hiring and promoting employees in a responsible way, the establishment of procedures for solving complaints, transferring or relocating employees, offering adequate health and safety and industrial hygiene conditions, professional formation, adequate payment and work time.

- The environment - a precautionary approach, evaluating and managing environmental risks, applying the "polluter pays" principle, taking into account a product's lifecycle, ensuring a clean and eco-efficient production process, approaching the product-service system, sustainable purchases, raising the awareness of the public.

- Business practices - an ethical behaviour of organizations in their relationships with other organizations.

- Consumer issues - The UN Guidelines for Consumer Protection. 
- Social involvement - organisations must be a "good citizen" in their communities.

The principles of social responsibility identified by the ISO 26000 standard are:

- Transparency - it must be applied with regards to decisions and activities that impact the environment and society.

- Assuming responsibility - the organization must be held accountable for the impact that it has on the environment, the economy and society.

- Ethical behaviour - the need for an honest, balanced and honourable organizational conduct.

- Respect for stakeholders' interests - recognizing their importance for achieving a sustainable development and paying special attention to those who do not have the means to organize and make themselves heard.

- Respecting the law.

- Respecting international rules on behaviour - the main rules used in international law.

- Respecting human rights - identifying and preventing any abuses.

\subsection{The European Union}

In recent times, corporate social responsibility has become an important matter for the European Union (the $\mathrm{EU})$.

The first-time corporate social responsibility entered on the EU Agenda was in 1993, when the president of the European Commission, Jaques Delors, made an appeal to the business environment to adopt a declaration against social exclusion (CSR Europe site). The European Business Declaration against Social Exclusion was adopted in 1995 by 20 leaders of Europe's business environment. In 1996, the European Business Network for Social Cohesion was established, later renamed as CSR Europe (CSR Europe site). It is a dialogue network between the European business community, the European Union and organizations active in this domain, which seeks to achieve good results and an increased efficiency in the fight against social exclusion.

In 2000, at the European Union Summit in Lisbon, the European Commission decided to elaborate the first EU-wide strategy on corporate social responsibility, so that "Europe can be capable of achieving a sustainable economic growth, with more and better paid jobs and a stronger social cohesion until 2010". The first Green Book of the European Union was published in 2001. The EU strategy on CSR was adopted in 2002. In 2001, the European Commission published its own definition of corporate social responsibility (The European Commission, 2001, p. 6): "a concept through which companies integrate their social and environmental concerns into their business activities and their interactions with stakeholder, in a voluntary manner".

At the same time, the CSR Europe network carried out its first major campaign to encourage companies to assume a more responsible business conduct. Furthermore, CSR Europe, together with a group of business academies and universities, founded the European Academy of Business in Society, with the goal of introducing the principles of corporate social responsibility into the university curriculum of future managers. The year 2005 saw the signature, by 400 business people, of an action plan titled "Towards a Competitive and Sustainable Enterprise" (CSR Europe, 2005), which became the foundation of the CSR Europe network in the following years and was included in the subsequent EU strategy adopted in this domain. In 2006, the EU Commission launched the CSR Alliance, which brings together the business community and several EUlevel business organizations, such as BUSINESS EUROPE, UEAPME and CSR Europe, in view of promoting the principles of social responsibility in Europe.

The Europe 2020 strategy, initiated in 2010, envisages a sustainable, durable and intelligent economic development over the course of the next decade (The European Commission site). In order to reach these objectives, the EU sets 5 priority areas that need to be taken into account, such as energy and climate change. The inclusion of the abovementioned areas shows that the European Union is directly concerned with the environment and its protection. At the same time, in October 2010, the CSR Europe Network launched the Enterprise 2020 program, in order to improve the coordination between EU institutions implementing the Europe 2020 Strategy and the actions of the business environment in the context of the CSR Europe network, which sought to expand the principles of corporate social responsibility among more and more European companies. 
In 2011, the European Commission published a new definition for the concept of corporate social responsibility, ten years after the first one (The European Commission, 2011, p. 6), which states that CSR is "the responsibility of companies for their impact in society". Between 2013 and 2015, the CSR Europe network carried out two EU-wide campaigns - Skills for Jobs and A Sustainable Lifestyle in the Cities, as well as a series of regional projects, all seeking to promote a responsible behaviour among business managers.

Another major European action in the field of CSR is the adoption, at the end of 2014, of the EU Directive no. 2014/95/EU, that imposes an obligation for "public interest enterprises" with more than 500 employees to publish on an yearly basis a non-financial statement containing information on environmental, social and employee-related aspects, the respect of human rights and the fight against corruption (EUR-Lex site). This directive must be implemented by EU member states until the end of 2016, and its application becomes mandatory starting with the fiscal year 2017. Public interest enterprises, within the meaning of the directive, are those companies that are listed on the stock exchange in any EU member state, as well as credit institutions, insurance companies and any entities classified as being of public interest by the member states, such as companies that have a major significance for the general public through their activities, size or number of employees.

These statements must include a brief description of the company's business model, a presentation of its policies with regards to the non-financial aspects mentioned above, the results of these policies and the main risks related to those aspects that are encountered during the operation of the company. The European Union recommends the use of international reporting standards such as the UN Global Compact principles or the OECD recommendations, but leaves the choice of reporting standards to each company. This directive is important for social responsibility because it improves transparency for companies operating in the European Union.

The fact that the environment is among the elements that need to be included in the report illustrates once again its importance and highlights the strong impact that economic activities have on it, which requires a higher level of social responsibility from the part of companies. In its current form, by defining the entities that must submit an annual report, Directive no. 2014/95/EU requires many companies having a significant environmental impact to inform the public about the concrete ways in which they assume their social responsibility.

\section{CONCLUSIONS}

From an environmental perspective, the concept of corporate social responsibility is becoming more and more important, due to the fact that economic activities have an ever-increasing impact on nature.

At an international level, most major corporations have accepted the principle of their responsibility towards society for the environmental impact brought about by their economic activities. This was followed by the adoption of internal operational policies meant to reduce the said impact.

Corporate social responsibility is not just an act of philanthropy or a fad, but a very serious behavior which should serve as a foundation for the actions of a company or corporation, one that will naturally lead to longterm profits.

\section{REFERENCE LIST}

Bowen, H. R. (1953). Social Responsibilities of the Businessman. Harper. New York

Cambridge Business English Dictionary (2011). Cambridge University Press. Cambridge

Carroll, A.B. (1999). Corporate Social Responsibility - Evolution of a Definitional Construct. Business \& Society, Vol. 38. No. 3. p. 268-295. Sage Publications. Inc. doi: $10.1177 / 000765039903800303$

CSR Europe (2005). An European Roadmap for Businesses. "Towards a Sustainable and Competitive Enterprise". CSR Europe. Bruxelles

CSR Europe website. http://www.csreurope.org/european-commission

Davis K. (1960). Can Business Afford to Ignore Social Responsibilities? California Management Review. p. 70-76

Davis K. (1973). The Case for and against Business Assumption of Social Responsibilities. The Academy of 
Management Journal, Vol. 16, No. 2. p. 312-322. doi: 10.2307/255331

Dictionary of the Romanian Language (2 ${ }^{\text {nd }}$ edition, revised and completed). (1998). Univers Enciclopedic Press. Bucharest

EU Directive no. 2014/95/UE of the European Parliament and the European Council of October 22, 2014. EUR-Lex website. http://eur-lex.europa.eu/legal-content/EN/ALL/?uri=CELEX:32014L0095

European Commission website. http://ec.europa.eu/europe2020/europe-2020-in-a-nutshell/index_en.htm

Free Audit website. http://www.freeaudit.ro/familia-iso/

Freeman E.R. (1984). Strategic Management- A Stakeholder Approach. Pitman. Boston. 292 p

Friedman M. (1970). The Social Responsibility of Business Is to Increase Its Profits. The New York Times Magazine. New York. p. 32-33, 122, 124, 126

ISO website. http://www.iso.org/iso/home/about.htm

La Viña, A., DeRose A. M., Escudero A. G., Ribot J., Hoff G., Bond P., \& Moniaga S. (2003). Making Participation Work: Lessons from Civil Society Engagement in the WSSD. World Resources Institute. Washington DC. Available on-line at: http://www.wri.org/publication/makingparticipation-work

OECD website. http://www.oecd.org/about/membersandpartners/

Romanian Ministry of Environment and Climate change website. http://www.mmediu.ro/beta/domenii/dezvoltare-durabila/concepte-si-principii-de-dezvoltare-durabila/

Romanian Ministry of Foreign Affairs website. http://www.mae.ro/node/1481

Romanian National Agency for Environmental Protection website. http://www.anpm.ro/ro/dezvoltare-durabila

The European Commission (2001). Green Paper for Promoting a European Framework for Corporate Social Responsibility. Bruxelles. Available online at:

http://www.europarl.europa.eu/meetdocs/committees/deve/20020122/com(2001)366_en.pdf. p. 366

The European Commission (2011). A renewed EU strategy 2011-14 for Corporate Social Responsibility. Bruxelles. $681 \mathrm{p}$.

The Global Compact Cities Program website. http://citiesprogramme.com/cities

The United Nations Conference on Environment and Development (1992). Rio Declaration on Environment and Development. Rio de Janeiro. United Nations Environment Programme website. Available on-line at: http://www.unep.org/documents. multilingual/default.asp?documentid=78\&articleid=1163

The United Nations (1992). Report of the United Nations Conference on Environment and Development Rio de Janeiro. 3-14 June 1992. Conference on Environment and Development. United Nations publication. New York. Available on-line at:

https://sustainabledevelopment.un.org/resources/documents

The United Nations (1997). Report of the United Nations Summit Rio+5. United Nations publication. New York

The United Nations (2002). United Nations Report of the World Summit on Sustainable Development. Johannesburg. South Africa

United Nations global compact website. https://www.unglobalcompact.org/what-is-gc/participants

United Nations website. http://www.un.org/en/sections/about-un/overview/index.html

World Commission on Environment and Development (1987). Our Common Future. Oxford University Press. New York. 400 p.

World Commission on Forests and Sustainable Development (1999). Our forests, our future. Cambridge University Press. Cambridge. United Kingdom 